\section{Endoscopic Management of Posterior Fossa Arachnoid Cyst in an Adult: Case Report and Technical Note}

\author{
Erișkinde Posterior Fossa Araknoid \\ Kistin Endoskopik Tedavisi: \\ Olgu Sunumu ve Cerrahi Teknik
}

\begin{abstract}
The authors report a case of large arachnoid cysts of the posterior fossa treated by endoscopic surgery. A 40-year-old man was admitted with a 3-month history of headache and progressive gait imbalance, with no significant medical history. At the time of admission, neurological examination revealed no abnormalities except for tandem imbalance. Brain computerized tomography (CT) scan and magnetic resonance imaging (MRI) revealed a posterior fossa arachnoid cyst (PFAC) causing brain stem compression accompanied by hydrocephalus. The patient was treated by endoscopic fenestration of the cyst with a paramedian suboccipital transcortical approach. Postoperatively the patient's complaints showed improvement and he was discharged with no complications. Follow up MRI showed a decrease in the cyst's size and the hydrocephalus with decompression of the brain stem.
\end{abstract}

KEYWORDS: Arachnoid cyst, Fenestration, Neuroendoscope, Posterior fossa

ÖZ

Bu makalede yazarlar endoskopik yöntem ile tedavi edilmiş büyük bir posterior fossa araknoid kist vakasını sunmaktadır. 40 yaşında ve özgeçmişinde özellik bulunmayan erkek hasta 3 ay süren başağrısı ve yürüme dengesizliği şikayetleri ile başvurdu. Başvuru zamanında yapılan nörolojik muayenede tandem yürüyüş dengesizliği saptandı. Kranyal bilgisayarlı tomografide(BT) ve manyetik rezonans görüntülemede (MRG) beyin sapı basısı ve buna bağlı hidrosefaliye neden olan bir posterior fossa araknoid kisti saptand1. Bu hasta paramedian suboksipital transkortikal yaklaşımı uygulanarak endoskopik yöntem ile ameliyat edildi. Postop dönemde hastanın şikayetlerinde gerileme görüldü ve komplikasyonsuz olarak taburcu edildi. Kontrol kranyal MRG'de kist ve hidrosefalinin boyutları azaldığ1 ve beyin sapı dekomprese olduğu görüldü.

ANAHTAR SÖZCÜKLER: Araknoid kist, Ağılaştırma, Nöroendoskopi, Posterior fossa

\section{Nurperi GAZIOGLU \\ Ali Metin KAFADAR \\ Necmettin TANRIOVER \\ Bashar ABUZAYED \\ Huseyin BICEROGLU \\ Nejat CIPLAK}

Istanbul University, Cerrahpaşa Medical Faculty, Department of Neurosurgery, Istanbul, Turkey

Received : 07.09.2009

Accepted : 24.09.2009

Presented in: Turkish Neurosurgical Society 23rd Scientific Congress, 17-21 April, 2009, Girne, Cyprus.

Correspondence address

Bashar ABUZAYED

E-mail: sylvius@live.com 


\section{INTRODUCTION}

Posterior fossa arachnoid cysts (PFAC) are welldefined, benign lesions. The effective treatment remains controversial, and there are only a few reports in the literature highlighting this issue $(3,6,12,14,18,21,24,26,29)$. Moreover, most of these reports are concerning the pediatric population. The natural history of PFAC is unknown and surgical treatment is indicated in symptomatic patients. The treatment modalities are open surgery with excision or marsupialization of the cyst, shunting procedure and endoscopic fenestration. New reports have demonstrated good clinical and radiological results in endoscopically-treated PFAC, with minimal invasiveness of this surgical procedure and the lack of a need for shunt implantation $(6,14,21,24,26)$.

In our case, endoscopic cisternostomy was performed in an adult patient, which is less frequently reported in the literature. In this report we attempt to highlight the advantages and the operative nuances of this technique.

\section{CASE REPORT}

A 40-year-old man was admitted with a 3-month history of headache and progressive gait imbalance, with no significant medical history. At the time of admission, neurological examination revealed no abnormalities except for tandem imbalance. Brain computerized tomography (CT) scan showed a cystic lesion with homogenous hypodensW content located in the posterior fossa, and accompanying hydrocephalus (Figure 1A,B,C). Brain magnetic resonance imaging (MRI) with gadolinium enhancement revealed a round cystic lesion compressing the 4 th ventricle and the brain stem in the posterior fossa, with content of the same intensity as CSF in T1- and T2-weighted images. The lesion did not show contrast enhancement. Ventriculomegaly was also obvious (Fig ure 1A,B,C).

Operative Technique: The patient was operated in the prone position. The lesion was approached by a left paramedian suboccipital skin incision and left suboccipital minicraniectomy. After dural opening and exposure of the left cerebellar hemisphere, the cyst was punctured with a Cushing puncture needle (Figure 2A,B), and the endoscope was introduced through this puncture tract. Inside the cyst, the aqueduct, the 4 th ventricle and its apex, the inferior colliculus, the facial colliculus, stria medullaris and the vestibular nucleus were identified behind the semi- transparent anterior wall of the arachnoid cyst (Figure 3A,B,C). Using the endoscopic monopolar, the arachnoid membrane overlying the apex of the 4 th ventricle and the orifice of the aqueduct was coagulated and resected delicately, as this was the safest zone for fenestration due to the sufficient safe space between the arachnoid cyst and the brain stem (Figure 4). After fenestration of the arachnoid cyst,

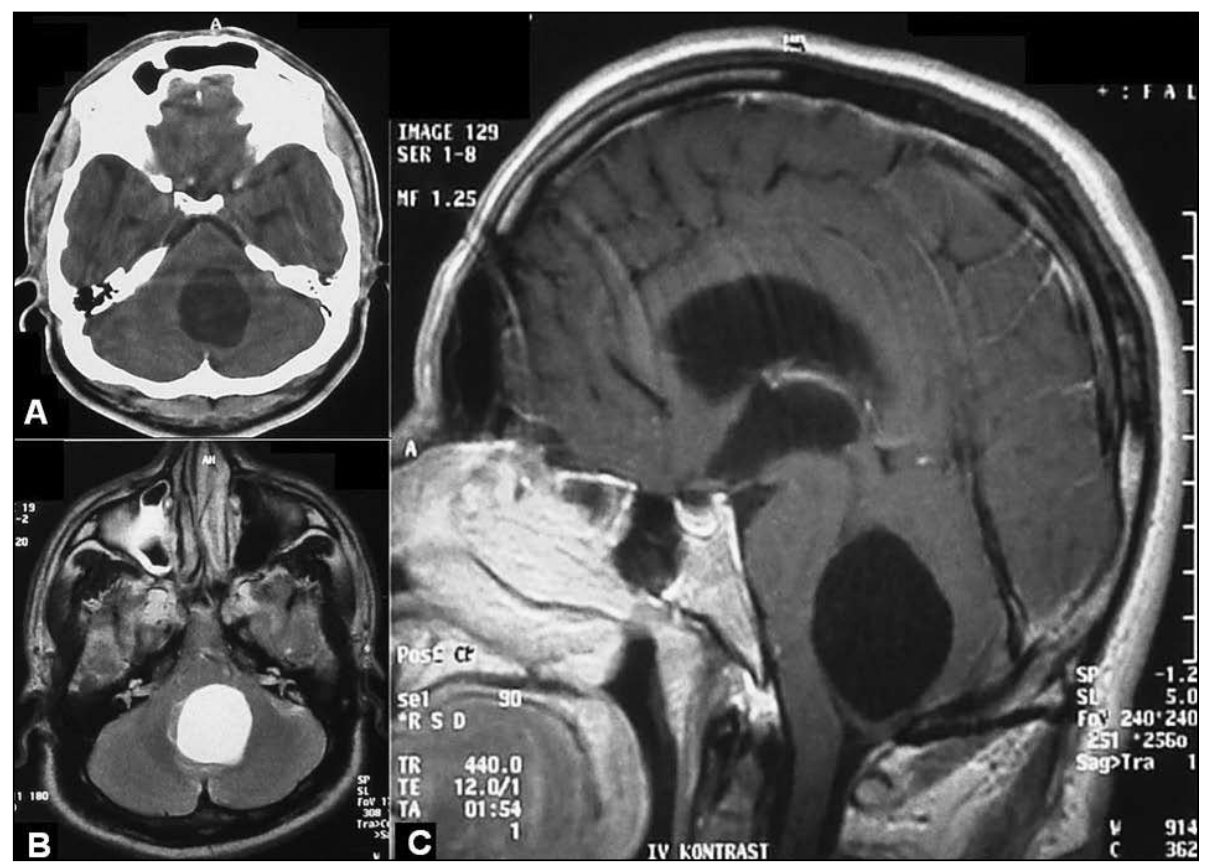

Figure 1: Preoperative brain $C T$ scan (A), T2-weighted (B) and T1-weighted MRI of our case, demonstrating the arachnoid cyst located in the posterior fossa and resultant brain stem compression. 


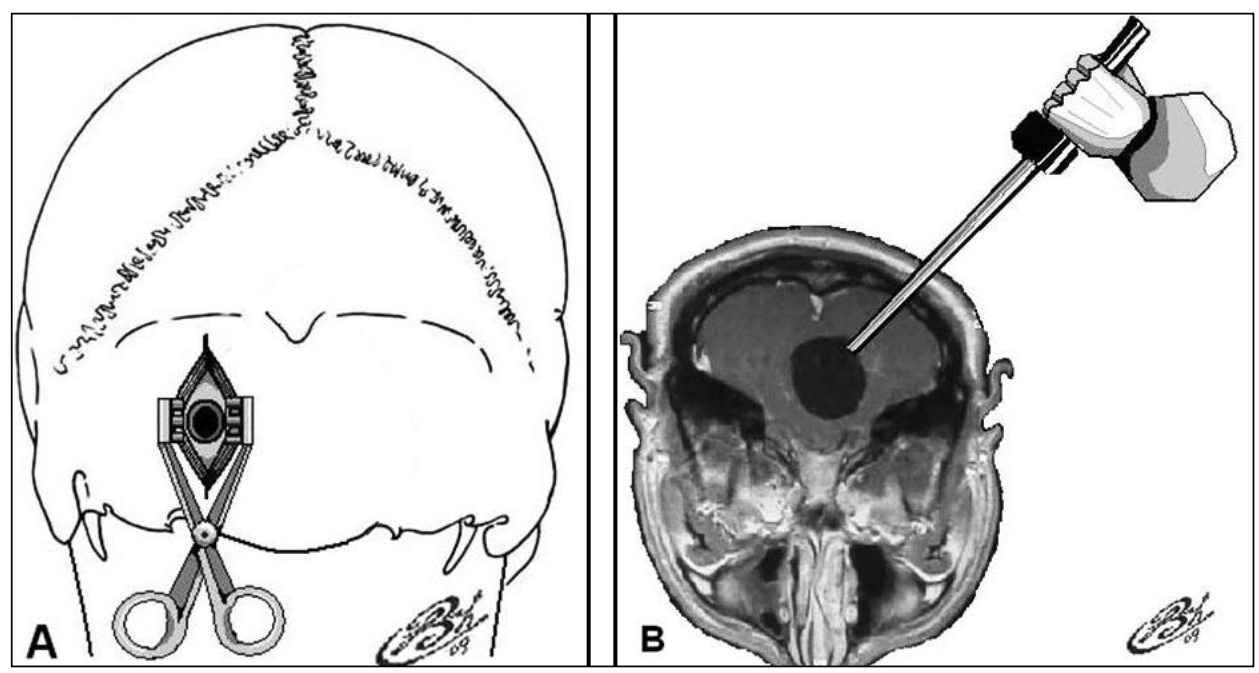

Figure 2: A) Schematic drawing demonstrating the paramedian suboccipital location of the burr hole. B) Schematic drawing demonstrating the entrance angle of the telescope toward the posterior fossa cyst.

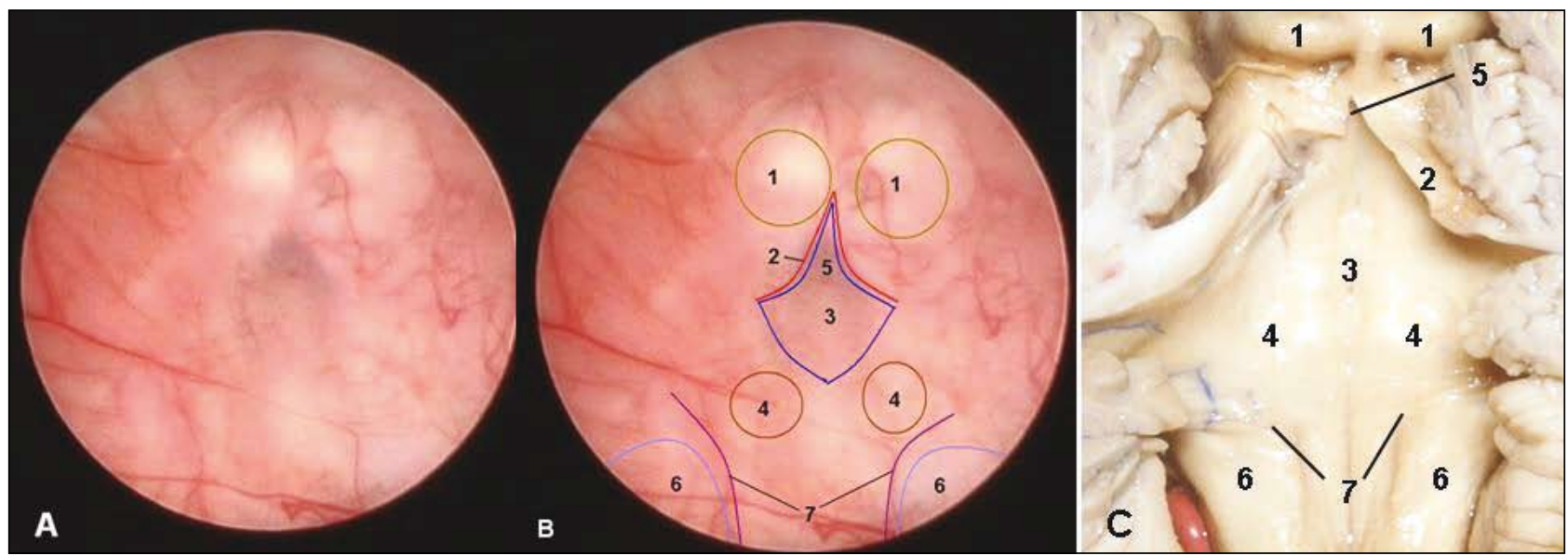

Figure 3: A) An intraoperative endoscopic view inside the cyst showing the anterior wall of the cyst and the brain stem behind. B) The anatomic landmarks of the brain stem are selected and demonstrated behind the anterior wall of the cyst. $C) A$ cadaveric dissection of the fourth ventricle and the brain stem compared to the endoscopic view in A and B (1. superior colliculus, 2. superior medullary velum, 3. fourth ventricle floor, 4. facial colliculus, 5. apex, 6. vestibular nucleus, 7. stria medullaris).

CSF flow was noticed by the pulsative movement of the cyst leaflets (Figure 5).

In the postoperative period the patient's complaints showed regression with improved gait balance. The postoperative brain MRI showed regression of the posterior fossa arachnoid cyst with significant decompression of the 4 th ventricle and the brain stem (Figure 6A,B,C). The patient was discharged without complications and clinical and radiological follow-ups showed no recurrence.

\section{DISCUSSION}

Arachnoid cysts are benign pathologies where an arachnoid-lined cavity is filled with a CSF-like fluid. This often causes disturbance in intracranial dynamics due to displacement of surrounding structures and intracranial hypertension $(30,38)$.

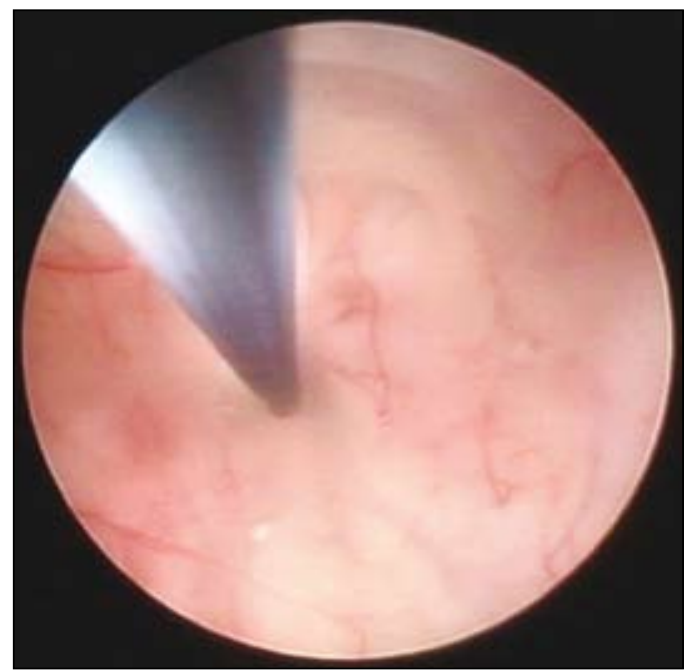

Figure 4: Intraoperative endoscopic view inside the cyst showing the monopolar coagulating the part of the cyst membrane overlying the aqueduct and the apex of the 4 th ventricle. 
Arachnoid cysts most probably arise from incomplete separation of the perimedullary mesh (endomeninx) during the early stages of embryogenesis (4). The mechanism by which arachnoid cysts expand and become symptomatic is still unknown although some mechanisms are suggested to explain this phenomenon. Expansion of the cyst can be related to the direct secretion of fluid from the cyst lining, by arachnoidal cells making up its wall, or by ectopic

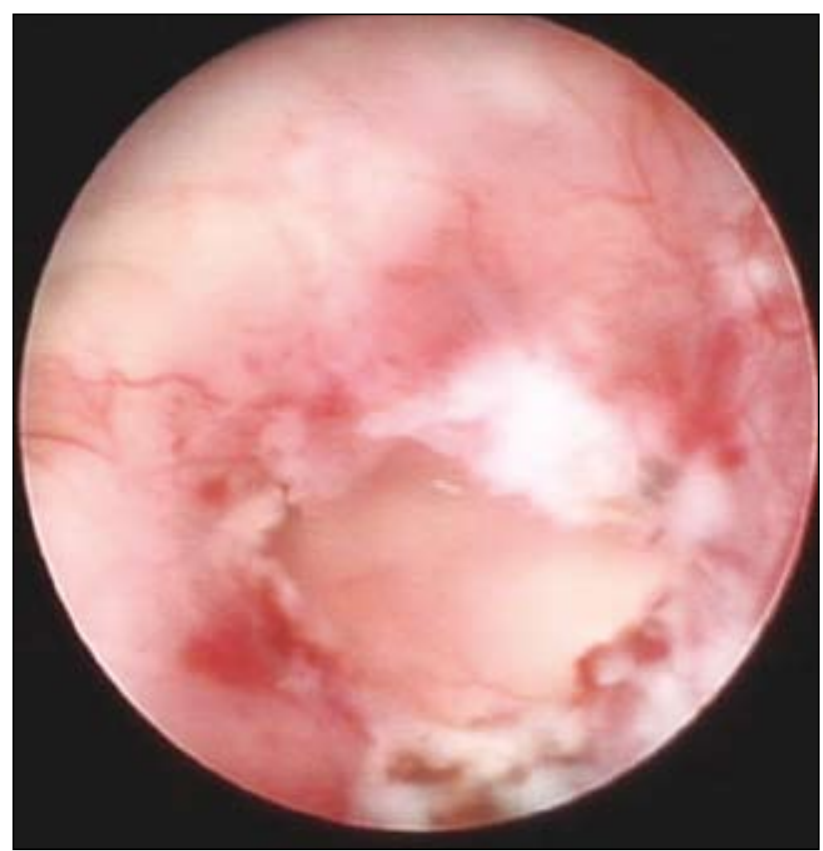

Figure 5: Intraoperative endoscopic view inside the cyst after fenestration of the anterior membrane of the cyst. choroid-like structures $(9,16)$. Also, arterial pulsations via a one-way valve in communicating cysts can contribute to cyst expansion. Other observations suggest osmotic gradient-induced intracystic fluid accumulation $(27,32)$.

There is a general agreement that prompt surgical intervention is indicated in patients presenting with symptoms of increased ICP or mass effect. Some authors mention the young age of the patients where an arachnoid cyst exerts a mass effect as an indication for surgical intervention even in the absence of symptoms $(13,34,35)$. This is because the potential for hindering normal development and function of the adjacent brain in this group outweighs the risk of operative treatment $(15,19,35)$. The surgical management of arachnoid cysts includes open craniotomy and marsupialization of the cysts, insertion of cystoperitoneal shunts, and more recently, neuroendoscopic fenestration of the cysts into the ventricles or cisterns. Complete removal of the cyst wall is not possible and has no extra benefit. Partial excision of the arachnoid cyst and opening of the basal cisterns or ventricles has proven to be an effective and safe procedure but open surgery for removal or fenestration is an aggressive procedure, and consequent complications are not uncommon (1).

Major complications of open surgery include meningitis, hemiparesis, seizure, subdural

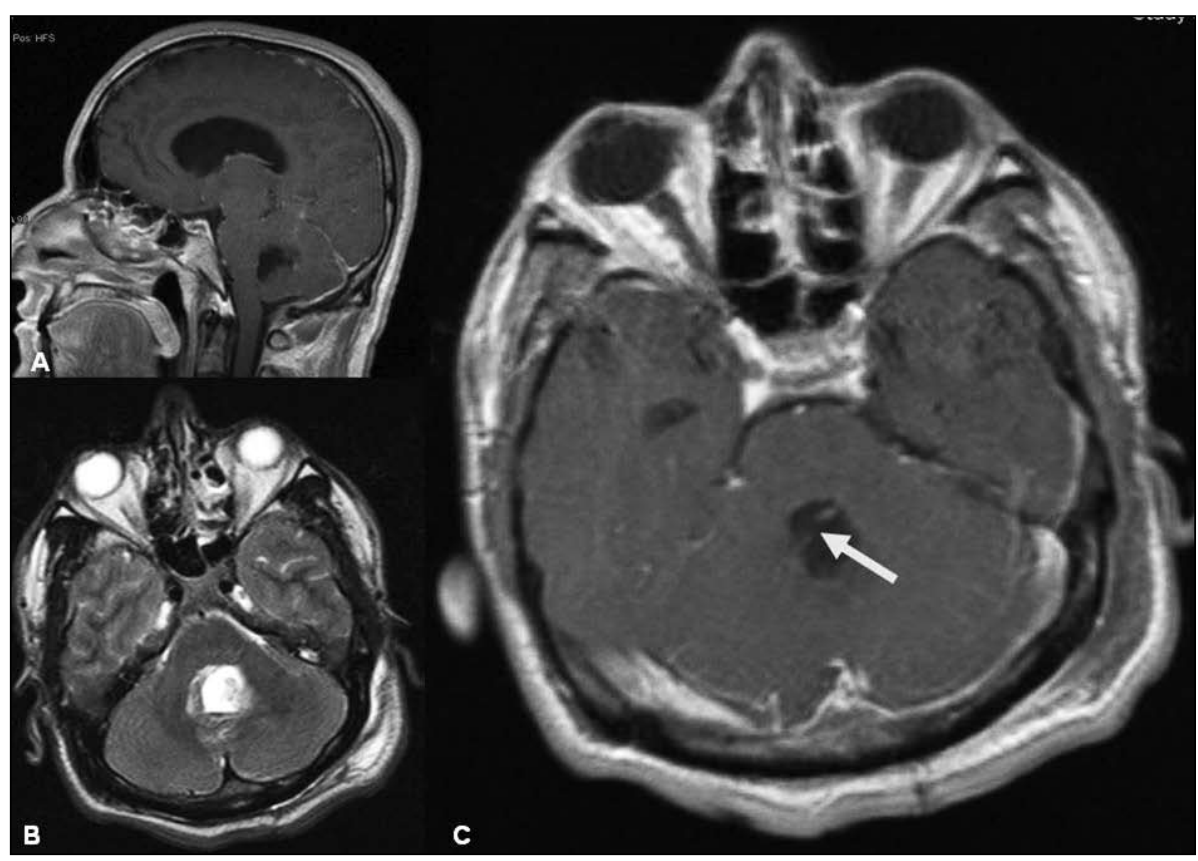

Figure 6: Postoperative sagittal T1-weighted (A), axial T2-weighted (B) and axial T1-weighted (C) MRI of our case, demonstrating the regression of the cyst size and decompression. 
hematomas, oculomotor palsy, and even death $(1,7,8)$. Moreover, an operation is not always effective and recurrence of the cysts has also been reported $(7,37)$.

Cysto-peritoneal shunting has proven to be a safer, simpler and more effective treatment method than open surgery, and is considered to be the best treatment of a large cyst in an infant or a young child. However, complications related to the shunting procedure such as obstruction, infection, hemorrhage and life-long shunt dependence are still not uncommon and should be considered $(2,31)$. The endoscopic approach in the management of arachnoid cysts has been proven to be an effective treatment method, as there is no life-long shunting dependence, no shunt-related complication and a low rate of recurrence $(5,6,17,20,22,35,36)$.

PFACs are well defined, easily detectable, and in the majority of cases, accessible lesions. However, the effective treatment remains controversial, and there are reports in the literature highlighting this issue $(3,6,12,14,18,21,24,26,29)$. These reports mostly concern the pediatric population, with the biggest series being reported by a European cooperative study that included 54 cysts at the posterior fossa from 17 institutions (27). The posterior fossa location represented the second most common location for arachnoid cysts after the middle cranial fossa $(14,28)$. Symptomatic cases mostly present with a history of increased head size and signs of increased ICP. Less common presentations include ataxia, hearing loss, and facial nerve palsy $(12,18,29)$. Hydrocephalus is considered very suggestive of the disease $(6,8,14,19,28)$ and di Rocco et al. found hydrocephalus in all of their eight patients with symptomatic PFAC (10). The association of other congenital anomalies is estimated to occur in 10 to $30 \%$ of cases $(23,25)$.

The natural history of PFAC is unknown; and surgical treatment is considered in symptomatic patients. The treatment modalities are open surgery with excision or marsupialization of the cyst, shunting procedure and endoscopic fenestration. Craniotomy with excision or marsupialization was considered a first-line surgical option in cases of PFAC (27) but some investigators elsewhere obtained good results with the use of shunting procedures despite the necessity for revisions $(3,8,11,28)$. The shunt revision rate was as high as $45 \%$ of cases in some reports (25). Thus, CSF shunting was identified as a negative factor due to the high incidence of shunt revision.
New reports have demonstrated the same good clinical and radiological results in endoscopicallytreated PFAC, with the minimal invasiveness of this surgical procedure and the lack of a need for shunt implantation $(6,14,21,24,26)$. The limited range of motion and size of instruments fitting into the working channels of the rigid endoscope is the main disadvantage. This may be especially important for the control of bleeding (6). Another disadvantage is the recurring problem after endoscopic treatment. This seems to be due to the toughness and vascularity of arachnoid membranes that prevents sufficient fenestration with delicate instruments (35).

Patients who were operated endoscopically showed a favourable outcome, with improvement of the clinical symptoms at presentation and a decrease in the lesion size in around two-third of patients $(24,33)$. CSF shunting can be considered as a secondline procedure because of the increased chance of shunt revision in the remaining one third of the cases.

In our case, endoscopic cisternostomy was performed in an adult patient, which is less frequently reported in the literature, as the majority of cases reported were concerning the pediatric population. In this case we preferred transcortical insertion of the endoscope. The advantages of this approach are the horizontal approach to the center of the cyst that is the widest portion. This provided safer and more comfortable manipulation of the telescope with wide exposure of all cyst angles. The transvermian approach may cause damage to the vermis with postoperative truncal ataxia; and the mutism syndrome, especially in children (39). Low approaches between or below the tonsils carry the risk of posterior inferior cerebellar artery (PICA) injury, as the endoscopic approaches are performed by a burr hole or minicraniotomy with limited exposure and control of intracranial contents. It is also difficult to manipulate the telescope to expose the inferior portion of the cyst due to the oblique insertion angle in this approach. At the same time, the shoulders of the patients can limit the directing of the endoscope to expose the superior portion of the cyst.

As we entered the cyst, we could expose the semi-transparent anterior wall of the cyst, and the aqueduct, the 4 th ventricle and its apex, the inferior colliculus, the facial colliculus, stria medullaris and the vestibular nucleus were identified behind this 
wall. With the endoscopic monopolar, the arachnoid membrane overlying the apex of the 4 th ventricle and the orifice of the aqueduct was coagulated and fenestrated delicately. We suggest that this is the safest zone for fenestration due to the sufficient safe space between the arachnoid cyst and the brain stem. Also, the fenestration of this zone will expose the aqueduct and this is useful if aqueduct stenting is decided on. During fenestration, we believe that an incorporated portion of the superior medullary velum with anterior wall of the cyst is also fenestrated, as it is located at the level of the aqueduct and the apex of the 4th ventricle. Nevertheless, we did not observe any complications or side effects related to this fenestration.

\section{CONCLUSIONS}

We believe that endoscopic fenestration of PFAC is an effective minimal invasive procedure that offers the opportunity of understanding arachnoid cyst physiology better and the advantage of avoiding a large craniotomy or the known complications of a cystoperitoneal shunt. However, these techniques require a slow learning process during which the surgeon accumulates invaluable experience.

\section{REFERENCES}

1. Aoki N, Sakai T: Intraoperative subdural hematoma in a patient with arachnoid cysts in the middle cranial fossa. Childs Nerv Syst 6:44-46, 1990

2. Aoki N, Sakai T, Umezawa Y: Slit ventricle syndrome after cystperitoneal shunting for treatment of intracranial arachnoid cyst. Childs Nerv Syst 6:41-43, 1990

3. Boltshauser E, Martin F, Altermatt S: Outcome in children with space-occupying posterior fossa arachnoid cysts. Neuropediatrics 33:118-121, 2002

4. Brackett CE, Rengachary SS: Arachnoid cysts. In: Youmans JR, ed. Neurological surgery, 2nd ed. Philadelphia: Saunders, 1982: 1436-1446

5. Buxton N, Vloeberghs M, Punt J: Flexible neuroendoscopic treatment of suprasellar arachnoid cysts. Br J Neurosurg 13: 316-318, 1999

6. Choi JU, Kim DS, Huh R: Endoscopic approach to arachnoid cyst. Childs Nerv Syst 15:285-291, 1999

7. Choux MC, Raybaud N, Pinsard N, Hassoun D, Gambarelli D: Intracranial supratentorial cysts in children excluding tumor and parasitic cysts. Childs Brain 4:15-32, 1978

8. Ciricillo SF, Cogen PH, Harsh GR, Edward MSB: Intracranial arachnoid cysts in children. A comparison of the effects of fenestration and shunting. J Neurosurg 74:230-235, 1991

9. Dei-Anang K, Voth D: Cerebral arachnoid cyst: A lesion of the child's brain. Neurosurg Rev 12:59-62, 1989

10. di Rocco C, Caldarelli M, di Trapani G: Infratentorial arachnoid cysts in children. Childs Brain 8:119-133, 1981
11. Erdincler P, Kaynar MY, Bozkus H, Ciplak N: Posterior fossa arachnoid cysts. Br J Neurosurg 13:10-17, 1999

12. Eslick GD, Hammond SR: Cystic lesion of the posterior fossa. Lancet 359:396, 2002

13. Galassi E, Piazza G, Gaist G, Frank F: Arachnoid cysts of the middle cranial fossa: A clinical and radiological study of 25 cases treated surgically. Surg Neurol 14:211-219, 1980

14. Gangemi M, Maiuri F, Colella G, Sardo L: Endoscopic surgery for large posterior fossa arachnoid cysts. Minim Invasive Neurosurg 44:21-24, 2001

15. Geissinger JD, Kohler WC, Robinson BW, Davis FM: Arachnoid cysts of the middle cranial fossa: surgical considerations. Surg Neurol 10:27-33, 1978

16. Go KG, Houthoff HJ, Blaauw EH, Havinga P, Hartsuiker J: Arachnoid cysts of the sylvian fissure: Evidence of fluid secretion. J Neurosurg 60:803-813, 1984

17. Greenfield JP, Souweidane MM: Endoscopic management of intracranial cysts. Neurosurg Focus 19(6):E7, 2005

18. Haberkamp TJ, Monsell EM, House WF, Levine SC, Piazza L: Diagnosis and treatment of arachnoid cysts of the posterior fossa. Otolaryngol Head Neck Surg 103:610-614, 1990

19. Harsh GR IV, Edward MSB, Wilson CB: Intracranial arachnoid cysts in children. J Neurosurg 64:835-842, 1986

20. Hopf NJ, Perneczky A: Endoscopic neurosurgery and endoscope-assisted microneurosurgery for the treatment of intracranial cysts. Neurosurgery 43:1330-1337, 1998

21. Karabatsou K, Hayhurst C, Buxton N, O’Brien DF, Mallucci CL: Endoscopic management of arachnoid cysts: An advancing technique. J Neurosurg 106:455-462, 2007

22. Kirollos R, Javadpour M, May P, Mallucci C: Endoscopic treatment of suprasellar and third ventricle-related arachnoid cysts. Childs Nerv Syst 17:713-718, 2001

23. Little JR, Gomez MR, MacCarty CS: Infratentorial arachnoid cyst. J Neurosurg 39:380-385, 1973

24. Marin-Sanabria EA, Yamamoto H, Nagashima T, Kohmura E: Evaluation of the management of arachnoid cyst of the posterior fossa in pediatric population: Experience over 27 years. Childs Nerv Syst 23:535-542, 2007

25. Menezes AH, Bell WE, Perret GE: Arachnoid cysts in children. Arch Neurol 37:168-172, 1980

26. Nomura S, Akimura T, Imoto H, Nishizaki T, Suzuki M: Endoscopic fenestration of posterior fossa arachnoid cyst for the treatment of presyrinx myelopathy -case report. Neurol Med Chir (Tokyo) 42:452-454, 2002

27. Oberbauer RW, Haase J, Pucher R: Arachnoid cysts in children: A European co-operative study. Childs Nerv Syst 8:281-286, 1992

28. Pascual-Castroviejo I, Roche MC, Martinez Bermejo AM, Arcas J, Garcia Blazquez M: Primary intracranial arachnoid cyst. Childs Nerv Syst 7:257-263, 1991

29. Pirotte B, Morelli D, Alessi G, Lubansu A, Verheulpen D, Fricx C, David P, Brotchi J: Facial nerve palsy in posterior fossa arachnoid cysts: report of two cases. Childs Nerv Syst 21: 587-590, 2005

30. Rappaport ZH: Suprasellar arachnoid cysts: options in operative management. Acta Neurochir (Wien) 122:71-75, 1993

31. Rengachary SS. Intracranial arachnoid and ependymal cysts. In: Wilkins RH, Rengachary SS, ed. Neurosurgery. New York: McGraw-Hill, 1985: 2160-2172 
32. Rengachary SS, Kennedy JD: Intracranial arachnoid cysts and ependymal cysts. In: Wilkins RH, Rengachary SS, ed. Neurosurgery, 2nd ed. New York: McGraw-Hill, 1996: 37093728

33. Richard KE, Dahl K, Sanker P: Long-term follow-up of children and juveniles with arachnoid cysts. Childs Nerv Syst 5:184-187, 1989

34. Schroeder HW, Gaab MR: Endoscopic observation of a slitvalve mechanism in suprasellar prepontine arachnoid cyst: Case report. Neurosurgery 40:198-200, 1997

35. Schroeder HW, Gaab MR, Niendorf WR: Neuroendoscopic approach to arachnoid cysts. J Neurosurg 85:293-298, 1996
36. Sood S, Schuhmann MU, Cakan N, Ham SD: Endoscopic fenestration and coagulation shrinkage of suprasellar arachnoid cysts. Technical note. J Neurosurg 102:127-133, 2005

37. Sprung C, Mauersberger W: Value of computed tomography for the diagnosis of arachnoid cysts and assessment of surgical treatment. Acta Neurochir (Wien) 28:484-500, 1979

38. Starkman SP, Brown TC, Linell EA: Cerebral arachnoid cysts. J Neuropathol Exp Neurol 17:484-500, 1958

39. Wells EM, Walsh KS, Khademian ZP, Keating RF, Packer RJ: The cerebellar mutism syndrome and its relation to cerebellar cognitive function and the cerebellar cognitive affective disorder. Dev Disabil Res Rev 14:221-228, 2008 